\title{
Foregrounding the Animal Stance: A Critical Study of Man- Eating Leopard of Rudraprayag
}

\author{
Parul Rani \& Nagendra Kumar \\ Department of Humanities and Social Sciences, Indian Institute of Technology Roorkee. \\ Email: parulnet.e@gmail.com. ORCID Id: oooo-0oo2-9934-3585
}

Received July 30, 2017; Revised September 01, 2017; Accepted September 18, 2017; Published September $20,2017$.

\begin{abstract}
The present article argues that the representation of the animals in the colonial texts try to reassert and reconfigure the colonial rule on the colonised subjects. Likely, the handling of the non-human animals by the colonials in sporting or non-sporting ways erects an invisible and persistent hegemonic control over the native land. As far as the processing of the big cat animals, particularly a man-eater is concerned; it emerges with convoluting the sound factors of race, gender and supremacy. The shooting of the man-eater animal by a white is purely a forefront which designs an imperial masculinity. Through a critical analysis of Jim Corbett's text Man-Eating Leopard of Rudraprayag, the study aims exclusively at: first, to explore the role of an animal (Leopard): a vital object in contouring masculinity. Secondly, to foreground the animal stance, questioning the human authorised version of a man-eater and the enduring human rule over the nonhuman animals. The discussion implants the leopard, a subject of explication, as an essential character; liable to his 'natural' proviso.
\end{abstract}

Keywords: Imperial masculinity, animals, the man-eating leopard, animal studies, Jim Corbett.

\section{Introduction}

The close relationship between colonial literature and animals, though explicit, but remains an incipient arena of exploration. The closing phase towards the independence of India, colonial writings about animals seem to chant the songs of conservation which leave the colonial rule in a positive light before fading out. The acclaimed hunter cum conservationist, who gained enormous respect and recognition in India, is Jim Corbett. As far as his narratives are concerned, it lacks a critical attention because his personality and reverence as a man-eater hunter overshadow the hunting phase of his life and apt for Shakespeare's title All's Well that Ends Well. The sight of the big cat animals and control over them result in the formation of manliness and power. The big cat animals: tiger, leopard and elephant particularly are the symbol of power, "Animals like the lion and tiger were often metaphors for power even as they were a source of danger" (qtd. in Rangarajan, 1998: 267). The historical glimpse of India confers the Kings and Princes playing, riding, domesticating and hunting these animals. The power in commanding the big cats used to leave the people open mouthed and surprised with happiness intermixed with fear. As Theodore Morison locates, "As the cavalcade winds down the narrow streets the men pick up their swords and hurry forward; the women and children rush to the doors of their houses, and all the people gaze upon their prince with an expression of almost ecstatic delight; as the elephant passes" (Morison, 1899: 49). The Whites do not take much time in understanding the significance of the

(C) AesthetixMS 2016. This Open Access article is published under a Creative Commons Attribution Non-Commercial 4.0 International License (http://creativecommons.org/licenses/by-nc/4.0/), which permits non-commercial re-use, distribution, and reproduction in any medium, provided the original work is properly cited. For citation use the DOI. For commercial re-use, please contact editor@rupkatha.com. 
animals in creating their superior empire and mastering over the native estate. Whenever the prevalent conflict between carnivores and the human life heightens, it is the obligation of the British official and the Government to get the indigenous people rid of the danger. The encounter with the dangerous beasts begets a masculine identity, which is unrivalled and dynamic and reminds of Sinha's words "manly Englishman" (Sinha, 1995:3). Masculinity is a category to analyse in this article since it is intensely entangled with the text The Man-Eating Leopard of Rudraprayag. The famous/infamous Rudraprayag leopard still haunts the minds of people whenever there is a tale about the man-eater. The frequent attempts and ways by the government to trap this maneater become futile till Jim Corbett's persistent pursuit resulted fruitful in 1926. The leopard reigns the Garhwal region of the United Provinces of British India for eight years, making an appearance in the news papers and magazines in India and abroad.

Hunting the wild animals and the pursuit of the man-eaters for shooting them are counterpart activities but looked upon from different perspectives. Former lies in enacting the skills of fair play and the latter is doubly acknowledged and worshipped since its disturbance to the humans' sole authorised world comes to an end. The animals decorate a platform for the empire to execute itself with masculine power and racial prestige in facing the danger of killing the man-eaters. "The imperial hunt was a largely male affair and extolled as such. Its rituals and its alleged character-forming qualities were depicted as being 'manly', a masculine training for imperial rule and racial domination" (Mackenzie, 1988: 22). All the narratives in the text extricate the incidences, ranging from 1918 to 1926 when Jim Corbett follows the man-eating leopard and tries his best to shoot him. The leopard that is the part of nature as is the human becomes the object of discourse and terror, terrorising the Garhwali people as they are fall prey to him. It is considered an 'evil' spirit of the night. But the posthumanist analysis of the text finds the different ways of the nature to deal with its requirements. It turns the argument to the leopard, whose gaze challenges the stereotype thinking of human supremacy over nature. The study tries to probe into the aspect of wild life which challenges the notion of Protagoras, "Man is the measure of all things" (qtd. in Sholarin, Wogu, Omole \& Agoha, 2015: 179). And Aristotle's concept which distinguishes man from other animals by calling him "rational animal" (qtd. in Weil, 2012: xv). The rationality of the humans creates the binary opposition of the stupidity of the animals at the base of man and animal differentiation. But the philosophical stance of Gilles Deleuze asserts that stupidity is proper to man, Derrida mentions in his lecture, "that Deleuze distinguishes what is

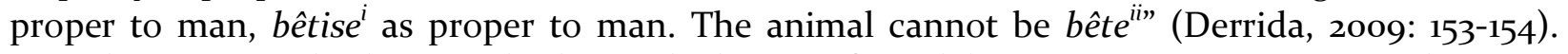
Derrida critiques the human thinking which is, in fact, delimitating its extent. He is the view, "The kind of thinking that has not been done and that has become all the more urgent to do is a thinking that happens through recognition and acknowledgement of the animals we are and with whom we share our world" (qtd. in Weil, 2012: xvi).

\section{The man-eating leopard: an object}

When Jim Corbett comes to the later phase of his fully fledged hunting, there was a surge of conservation of the wild life under the British Government. Although many critics acknowledge this action initiated for fear of only loss of the game, the immense popularity of Corbett rests upon eliminating the man-eaters and a major face of conservation. The beginning of the twentieth century in India establishes the different aspect of imperial masculinity as a manifestation of “"virtuous" rule of British Raj" (Patterson, 2009: 1). It lies in the care of nature and service of the natives who are effeminate, meant to be the followers of the Whites. "A supposed masculine ideal identified by a love of sports, particularly hunting...a vigorous pursuit of play...all contributing to the 'manly character' which was seen as the well-nigh unique mark of the 
Briton" (MacKenzie, 1995, vii). The articulation sounds same when Corbett follows the Rudraprayag man-eater stoutly. "There were twenty four hours in every day of many weeks I spent in Garhwal, and time and time again after sitting up all night, I walked endless miles next day, visiting distant villages from which reports had come of successful attacks by the man-eater" (Corbett, 2014: 77). The vigor and fortitude, shown by Corbett feature the imperial masculinity in opposition to nature, particularly the leopard.

The news of the emergence of a man-eater in an area creates a compelling shock, and such resemblance is with the case of the Rudraprayag man-eater. The popularity of this man-eater partly rests upon the region; he is active in. Since Rudraprayag is on the leading road of the pilgrimage to Kedarnath, it becomes quite accessible for the leopard to come in contact with the people. There are twenty-five stories in the text including epilogue which depicts various stages and ways of chasing the man-eater. There is a sense of a competition of the heroism between leopard and Corbett. It binds to the thrill of who is going to be the winner/hero. Since leopard is a nocturnal animal, it adds more difficulty in tracking the man-eater and shooting him in the dark of the night. Despite the fact that, "there were over four thousand licensed gun-holders in Garhwal, and host of keen sportsmen in Lansdowne" (Corbett, 2014: 22), no one was willing to risk his life. So the task is assigned to Jim Corbett, and his acceptance depends upon his sportsmanship and prestige, he has earned in his life. "The civilian administrator developed a patriarchal approach to hunting in many parts of India, seeing it as an obligation, a source of prestige, a route to understanding his district and people, as well as a means of recreation" (MacKenzie, 1988: 168).

"The Pilgrim Road", the opening story reveals many strands which are tied together in the upcoming course of the text. Largely, Hindus inhabit the Garhwal region, so Corbett makes his invisible companion as Hindu who is a pilgrim and travels with him up to Rudraprayag. The hardships of the pilgrimage to the sacred shrines of Kedarnath and Badrinath are the means of being rewarded, as Hindus believe:

Times there will be, a-many, when, gasping for breath, you toil up the face of steep mountains on feet torn and bleeding by passage over rough rocks, sharp shale, and frozen ground, when you will question whether the prospective reward you seek is worth the present price you pay in suffering; but being a good Hindu you will toil on, comforting yourself with the thought that merit is not gained without suffering (Corbett, 2014:3).

The pilgrimage serves two ways: the availability of the people in the range of the man-eating leopard and the leopard's popularity also depends on the pilgrimage. "Garhwal can claim that this leopard was the most publicized animal that has ever lived, for he was mentioned - to my knowledge - in the press of United Kingdom, America, Canada, South Africa, Kenya, Malaya, Hong Kong, Australia, New Zealand, and in most of the dailies and weeklies in India" (Corbett, 2014: 6). The fame of the man-eater and the prestige of its hunter are firmly related. As the government appeals to all the sportsmen over the country for hunting the man-eater, Corbett's sportsman attitude in facing the danger of a significant nocturnal cat justifies Englishman masculinity. The series of the subsequent torment, Corbett faces in the jungles, makes him a hero from the humanist point of view. Since he is in the Garhwal for barricading any further loss to human life, the local people assist him at their best. Hunting of the big cat animals for sports designs the image of the hunter as a man of value and dignity. "Hunting for sport was integral not only to the lifestyle of the officials but also to their self-image as men who believed in fair play. The white man was considered 'superior' to the native and the Raj was seen as powerful enough to contain danger" (qtd. in Rangarajan, 1998: 265). The esteem of the masculine power in facing 
danger gets intensified when execution takes place for the sake of the colonised population. The animals are a defining factor in what is meant to be human as is the view of Rajmannar, "the animal constituted a central element in the defining of what it meant to be human, or, more relevantly...an Englishman" (Rajamannar, 2012: 22).

The area of the man-eater is conspicuously pleasing as this great portion of five hundred square miles is divided into two parts by Alaknanda River which meets Mandakini River at Rudraprayag. The icy cold water of the rivers and the cool breezing on the hills, particularly at night, make it more challenging to pursue a man-eater in the dark. The articulation; "My object in going to Rudraprayag was to try to prevent further loss of human life" (Corbett, 2014: 33) consolidates his love for the people of Garhwal. In the following of the man-eater, the other animals are also put at stake, "I decided to treat all leopards in the vicinity of Rudraprayag as suspect, and to shoot any that gave me a chance" (Corbett, 2014: 36). And other animals: goats, buffalos, cows, sheep, etc. are used as the bait and for installing the cyanide poison to kill the leopard but all result in vain. There are certain attractive stories about the leopard; designating him an 'evil spirit' of the night which signifies the superstition of the Garhwali people and simultaneously they credit Corbett with the supernatural power. Hitherto, the leopard is put to the dark side and is an enemy of the people. At times, the description of the leopard mentions, "when I could imagine the man-eater as being a big, light-coloured animal - for so he had appeared to me the first time that I saw him - with the body of a leopard and the head of a fiend" (Corbett, 2014: 19). The redemption from this enemy is the central motif of all the population/humans. Corbett as an epitome of saviour seems to challenge the leopard, considering it merely an animal when he says over the kill of a woman, "For this pitiful kill leopard would have to pay with his life" (Corbett, 2014: 100). It displays not only the image of an animal in the empire rather enacts a fearless and determined imperial masculinity which follows the vigil nights on the pine tree, rainy nights in the jungle and endless walk on the hills in search of the leopard. Sir William Ibbotson, Deputy Commissioner of Garhwal also accompanies Corbett in the arduous expeditions while local people's business confines only to torch bearers, drum beaters, informers and serving eatables to the whites:

Fifty yards from the tree, while climbing over a rock, Ibbotson slipped...we eventually reached the footpath our troubles were not ended, for the path was a series of buffalo wallows, and we did not know where our men were. Alternately slipping on wet ground and stumbling over unseen rocks, we eventually came to some stone steps which took off from the path and went up to the right (Corbett, 2014: 67-68).

All the efforts are put against an animal that is creating a huge menace in the human life. The animal becomes a sight of convincing the colonised over the colonial rule as constructive and an awareness of safety is refashioned through the determined chasing of the carnivorous, distinctly man-eaters. It resonates with Plumwood's argument, "the western definition of humanity depended - and still depends - on the presence of the 'not-human': the uncivilised, the animal and animalistic" (qtd. in Huggan and Tiffin, 2009: 5). Corbett and Ibbotson's crucial fruitless attempts in killing the leopard: the creaking of the plank, resulting in Ibbotson's changing position to relieve the painful cramp in his leg, rift in the gin trap tooth and the failure of the light in reloading the rifle finally result in boldness and conviction in the destruction of the animal. It seems a disgrace to the human rationality and power which fails in trapping an animal. The use of the rifle adds substantial strength to human body and is one of the most important weapons of the empire; Taylor termed it, "weapon of manhood" (Taylor, 2007: 160). The empire's viewpoint on the rifle is apparent in the lines, "having discarded poisons and traps, I would get an 
opportunity of using my rifle as rifles were intended to be used, to put a bullet truly and accurately into the man-eater's body" (Corbett, 2014: 109). The use of the rifle is marked with the sportsman's gusto. And the sportsman spirit leads Corbett to Golabrai where he shot the maneater in the dark in May 1926. The killing of the leopard gives a curve to the discourse as the animal's view which was buried till now is unearthed. The innocent seemed chin of the leopard rests on the edge of the hole and appears, "But here was no fiend, who while watching me through the long night hours had rocked and rolled with silent fiendish laughter at my vain attempts to outwit me...the best-hated and the most feared animal in all India, whose only crime-not against the laws of nature, but against the laws of man" (Corbett, 2014: 158). "The laws of nature' which have attracted the attention of the recent scholarship due to the present day environmental crisis is the essential aspect of scrutiny because the study remains incomplete without explicating the animals' version of the man-eater.

\section{The man-eating Leopard: a subject}

The encounter between human and the animal (leopard) though notorious as a man-eater, enforces me to probe the other aspect (of the animal) which abides by negligence in the hue and cry of the human loss in the narratives. The contemporary slogans and cries over 'save the wildlife' create the urgency to excavate the 'thinking' which led to the current scenario and knits a thread between past, present and the future of the wild life. The thought which makes a distinction between two animals: human as rational animal and animal as an irrational animal. And the same thought leads to the projection of human in the positive light where, "For centuries nonhuman animals have been locked in representations authored by humans, representations that moreover have justified the use and abuse of nonhuman animals by humans" (Weil, 2012: 4). And animals are categorized substantially in a negative way, as they are, "deprived of whatever is presumed to be "proper" to the human: "speech, reason, experience of death, mourning, culture, institutions, technics, clothing, lying, pretense of pretense [feinte de feinte], covering of tracks, gift, laughing, tears, respect, etc." (Mallet, 2008: x). There are certain propositions which need addressing: is it the philosophical stance which makes animal intrinsically inferior to man? Or is this the same position where man initiates his breakdown by mastering over the other species?

Recent scholarship in animal studies questions the distinction between animal and human and the treatment, the animals have undergone by in the name of power, rationality, difference, and otherness and so on. The narratives are the witness to register the otherness which the leopard endures irrespective of the reasons and nature of a carnivore, which Nature has thrust upon him. The resentful demeanour towards the man-eater in the text is pathetic on account of the cause and effect relationship between humans and the leopard's turning to be a man-eater. It invokes the proposition, Jeremy Bentham made for the non-human animals, "the question is not, Can they reason? nor, Can they talk? but, Can they suffer?" (Web, 16/o8/2017). Is this the suffering of the leopard that he is undergoing the phase of man-eater? Or is it not the suffering that he has become man-eater? Derrida addresses the question of Bentham on animal suffering in his lecture,

The response to 'can they suffer?' leaves no doubt. In fact it has never left any room for doubt; that is why the experience that we have of it is not even indubitable; it precedes the indubitable, it is older than it. No doubt either, then, about our giving vent to a surge of compassion, even if it is then misunderstood, repressed, or denied" (Derrida, 2008: 28).

The question on the animal suffering is very pertinent to revise while studying on a man-eater animal. It challenges the cultural tradition of being blinded to the distress of the other-thanhuman animals. In the similar context, it becomes indispensable to throw light on Corbett's contention: 
Leopards do not become man-eaters for the same reasons that tigers do. Though I hate to admit it, our leopards - the most beautiful and most graceful of all the animals in our jungles, and who when concerned or wounded are second to none in courage-are scavengers to the extent that they will, when driven by hunger, eat any dead thing they find in the jungle...when disease in epidemic form sweeps through the hills, and the inhabitants die faster than they can be disposed of, a very simple rite, which consists of placing a live coal in the mouth of the deceased, is performed in the village, and the body is then carried to the edge of the hill and cast into the valley below. A leopard, in an area in which his natural food is scarce, finding these bodies, very soon acquires a taste for human flesh, and when the disease dies down and normal conditions are re-established, he, very naturally, on finding his food supply cut off, takes to killing human beings. In the wave of epidemic influenza that swept through the country in 1918 and that cost India over a million lives, Garhwal suffered very severely, and it was at the end of this epidemic that the Garhwal man-eater made his appearance (Corbett, 2014: 4-5).

First, the articulation 'driven by hunger' and 'an area in which his natural food is scarce' bring robustness to the analysis as it is one of the leading reasons for the conflict between humans and wild life and moreover within the leopard itself. Hunger compels to go beyond the natural dietary habits of the carnivores. Lack of the natural prey in the area makes a carnivore to step out of his habitat and find out an alternative in the form of the human being. Sanderson throws light on the habits of leopard and sometimes how they come in conflict with the people, "From the habit of lurking in the vicinity of the habitations of man, to prey upon cattle, ponies, donkeys, sheep, goats and dogs, the panther and leopard are frequently brought into collision with Indian villagers...bite the claw half-a-dozen people before he is dispatched or makes his escape is no uncommon in India" (Sanderson, 1983: 329-330). In generating the deficiency of the natural prey of the carnivores, hunting played a disastrous role, terribly prevalent in colonial India. Deer, buffalo, goat, antelope, etc. are hunted at an immense scale while these animals stand at the second rank, and the prestige lies in hunting the big cat animals, particularly tigers. There is the human invasion into the wild life and disturb the natural ecological system. As the carnivores require a broad range of area as their habitat but the shrinking of the natural regions with the increasing of human population or the people's intrusion into the wild life territory for their livelihood is again an act of inviting the danger. Secondly, the ritual of disposing of the dead bodies in epidemic time signifies the human indigent reasoning and vulnerability, which circularly proves a threatening to the people. Studies have shown that leopards are very adaptable and try to survive on the availability of the food, "leopards are very catholic in their diet, tending to take whatever is available in the area" (qtd. In Edgaonkar \& Chellam, 2002: 354). And finally, the emergence of the Rudraprayag man-eater in 1918 is credited to all the human actions responsible for it. The leopard comes under a safeguard of a natural process of becoming a man-eater. It flares up the imagination of an animal's suffering in search of his food and the loss of his habitat. Again the statement that leopards 'when concerned and wounded are second to none in courage' substantiates the nature of the leopard who firmly believes in retribution. Undoubtedly, the carnivores are the dangerous animals full of acute mental and physical power and awareness which the leopard shows in dealing with his prey in the text.

The appearance of the man-eater after the epidemic in Garhwal justifies his fondness for the human flesh. In scientific terms, it is the cause and effect relationship, performed by the maneater which results in 126 human killings, mentioned in Government records. Before categorising the leopard as an 'evil spirit', 'a fiend' or 'a shaitan' and a destroyer of the human life, it obligates a revision to probe into the villagers' vulnerability which is lying across the relationship between 
man and nature. The poor people and Rudraprayag pilgrim road provide a right amount of food to the leopard in the form of humans, which he is waiting for. The threat, the man-eater is imposing on the villagers to a far extent is their dependency on the jungle for earning their livelihood and the lack of protection they can arrange for themselves. It is the limitations of the Garhwali people who insist the leopard obliquely enter the human domain.

The paper argues that the factors of race, class and gender intertwine together as far as the affair between the man-eater and his victims are concerned. Since a large number of villagers are not exposed to the weapons of prestige: rifle, gunshot, cartridges etc., so remain defenceless and depend on the whites for their protection. The poverty of the villagers forces them to risk their lives and expose to the attack. The assertion, "there are no sanitary conveniences in the houses of our hill-folk" (Corbett, 2014: 64) adds weight to the vulnerability of the poor folk and their capability of inviting the peril increase. In the beginning years of the man-eater, the leopard kills the people who, with due respect to their financial fragility, are readily available to him. The social, cultural and religious way of life also, of rural people, makes them sacrifice their lives at the hands of the man-eater. The sadhu, on his pilgrimage to Badrinath, prefers to sleep at the open platform adjoining the shop, serves himself as the first and convenient victim to the man-eating leopard. The twelve-year old Gujar girl in the story "Terror" becomes a prey to the man-eater while sleeping in the camp of his father in the jungle, settled for herding the thirty buffaloes. Women's going for sanitation at night is a sight of fulfilling the leopard's wish. The brief description of the hill folk and the locale notifies:

The houses are small and without conveniences or means of sanitation, and it would not be surprising if, hearing the man-eater was operating in a village ten, fifteen, or twenty miles away, some man, woman or child should, at the urgent dictate of nature, open a door for a brief minute and so give the leopard the chance for which he had perhaps been waiting many nights (Corbett, 2014: 35).

There are a lot many people who come across the leopard's hunger as a depressed class man, Gawaiya builds a home in the forest area for his family and offers himself as open bait. "Gawaiya had been sitting near the door of the house when the leopard had seized him. The leopard had caught the unfortunate man by the throat, thus preventing him from making any sound" (Corbett, 2014: 93), the man-eater is creating nuance on both the sides of the Alaknanda river as well as on the pilgrim road. Mukandi Lal, member of Garhwal in the United Provinces Legislative Council, in his report to the council states that "seventy-five human beings had been killed by the leopard in the course of that one year and asked the Government to launch a vigorous campaign against the man-eater" (Corbett, 2014: 133). On the other side, the leopard develops the habit to prey upon the pilgrims.

The inquiry of the text finds the role of the gender and age are other crucial aspects to examine. Most of the victims, elaborated by Corbett in the narratives, are women and children. Since the women in hilly areas are not limited only to the household work and very often visit the forests for collecting woods or grazing the cattle, so it becomes entirely possible for them to encounter with the wild animals. And moreover, their household work too exposes them to danger at night. The leopard secures his second kill in the form of a pregnant female while washing the utensils in the dark after the meals, "On reaching the door the woman sat down on the doorstep, as she did so the utensils clattered to the ground. There was not sufficient light for the man to see what had happened, and when he received no answer to his urgent call he dashed forward and shut and barred the door" (Corbett, 2014: 37-38). The story "Touch and Go" mentions another woman's ruthless slaughter while closing the door of her house. Furthermore, the small 
children become prey to the man-eater by virtue of their innocence and unknowingness of the presence of the leopard in the vicinity just as the little Gujar girl (has already been discussed) and the last victim of the man-eater, a twelve-year-old boy unknowingly approaches the leopard.

No doubt, the interactions between human and other-than-human animals has attracted the attention of the recent studies, particularly because of the questions that the animal rights and animals studies raise against the treatment, behaviour, marginalisation, including all the basis, which claim rightful domination of the humans over animals. When there is a discussion on the use of animals in literature and their portrayal, it becomes essential to evaluate the animals' position critically. Although the title character is characterised as a dangerous wild beast, Corbett's statement at the death of the leopard, "here was no fiend" (Corbett, 2014: 158) brings a contradiction to the text. Further, this animal breaks the boundary of the core differentiation in the form of 'rationality' between human and animal. The leopard is attributed with the intelligence to deal with the human beings and wild animals as well whether it lies in following up Corbett and Ibbotson silently, finding out his food, avoiding the cold Alaknanda river water, hearing the plank sound, avoiding the cyanide poison in the carcass or changing his habit to far extent when in contact with the people from a long time. The text seems to justify Deleuze's statement ironically, "Bêtise is a human thing and not that of the beast" (qtd. in Derrida, 2009: 152). Deleuze puts his views:

Stupidity [bêtise] is not animality. The animal is protected by specific forms which prevent it from being 'stupid' [bête]. Formal correspondences between the human face and the heads of animals have often been composed; in other words, correspondences between individual differences peculiar to humans and the specific differences of animals. Such correspondences, however, take no account of stupidity as a specifically human form of bestiality" (Deleuze, 1968: 150).

The text seems to consolidate the propositions of Deleuze where stupidity runs in the actions of the humans and ultimately results in the bestiality, ignoring the animals' pleasures and pains and their nature as a whole. (Bestiality is used as torture or barbarity, not as a zoophilic aberration). Other than the man-eater, the narratives discuss the leopard in general, and the cruelty is done to them only for sports or profit. There is a painful detail of the ruthless animal killing:

The most exciting, and the most interesting, method of killing leopards for sport is to attack them down in the jungles and, when they are located, stalk and shoot them. The easiest and the most cruel, method of killing leopards for profit is to insert a small and very highly explosive bomb in the flesh of an animal which are been killed by a leopard...when one of them comes in contact with the leopard's teeth, it explodes and blows the leopard's jaws off. Death is instantaneous in some cases, but more often than not the unfortunate animal crawls away to die a lingering and very painful death (Corbett, 2014: 28).

It exhibits the ostentations of the humans in killing a big cat, and the shrewd and tyrannical attitude towards the wildlife suffers from evasion. Such actions blur the differentiation between 'humanity' and 'animality' and put the question on both the terms which have been so long the basis of the essentialized othering of the animals.

\section{Conclusion}

When Humanities and Animal Studies inflict together, it bears upon some limitations as animal studies become the part of cultural studies and evade the scientific elucidation. Similarly, the present article has gone through the human and nonhuman animals' interaction and to 
understand the animals' and humans' living cultural estate. The study finds a sharp strife between the Garhwali people and the leopard. On the one hand, the animals play a significant role in the lives of the people: poor, middle or aristocratic class provided the varying cultural values of them but remain in the perpetual 'other' form only. Although the title character is an animal, its significance lies beyond an animal's identity and is also a cultural construction on which the masculine identity of the colonials rather the 'humans' (I must emphasise) is structured. The efforts of the government to kill the man-eater and control the turmoil in the man-eater vicinity furnish the insight into a wider perspective that all the possible actions taken by a superior race are for the well-being of the rural India. The kill of the evil or fiend man-eater makes Jim Corbett Godlike among the Garhwali people and a sahib who is an Englishman by virtue and identity and is full of supernatural power and unyielding determination as far as hunting is concerned. Corbett's love for the human race is apparent but his imperial masculinity and eco-sensibility which was evolving out of his close encounter with the wildlife in the Indian jungles, are stuck together and can be seen when the 'laws of nature' come into consideration. On the other hand, the study locates the natural encroachment and the Garhwali people's susceptibility as the prime factor for the man-eater's fondness for the human flesh. There is a vigorous prejudice against the humans as a species of high and prime importance whose loss becomes the loss of all. While the lack of natural habitat and food of the carnivores including their sufferings, requirements, pains and pleasures completely lack attention. The emergence of the man-eater is reasonspecific/human-specific and not a natural recurring occurrence. Furthermore, it is misleading to categorise the animals straightforwardly 'irrational' as scrutiny of the text puts a question on this irrational agency and discovers that a lot can come out of a rational thought of the animals and close engagement with them.

\section{Notes}

${ }^{\text {i }}$ bêtise is a French word, originally used by Gilles Deleuze in Difference and Repetition, deriving the meaning "stupidity". Jacques Derrida uses this term extensively in his lecture series, presenting his deep insight on the concept of the animal. The lecture and seminar series of Jacques Derrida of the year 2001-02, in the form of book is titled as Beast and the Sovereign Volume I, edited by Michel Lessi, Marie-Louise Mallet and Ginette Michaud and translated into English by Geoffrey Bennington.

ii bête is also a French word, originally used by Deleuze in Difference and Repetition as "stupid". Jacques Derrida uses this term for interrogating the attributed characteristics to humans and the animals as wisdom and stupid respectively, in Beast and the Sovereign Volume I. In the present article, bête is used as 'stupid' in an adjective form.

\section{References}

Bentham, J. (16/o8/2017). Jeremy Bentham on the Suffering of Non-human Animals. Retrieved from $<$ https://www.utilitarianism.com/jeremybentham.html>

Corbett, J. (2014). The Man-Eating Leopard of Rudraprayag. New Delhi: Oxford University Press. (First published in 1947).

Deleuze, J. (1994). Difference and Repetition. Paul Patton (Trans.). New York: Columbia University Press.

Derrida, J. (2008) The Animal That Therefore I Am. (Ed.) Marie-Luise Mallet. New York: Fordham University Press.

Derrida, J. (2009). Beast and the Sovereign Volume I. (Ed.) Michel Lisse, Marie-Louise Mallet and Ginette Michaud. Geoffrey Bennington (Trans.). London: The University of Chicago Press. 
Edgaonkar, A., \& CHELLAM, R. (2002). Food habit of the leopard, Panthera pardus, in the Sanjay Gandhi National Park, Maharashtra, India. Mammalia, 66(3), 353-36o. Retrieved from <http://booksc.org/book/18536156/ff927a>

Huggan, G. \& Tiffin, H. (2009). Postcolonial Ecocriticism: Literature, Animals, Environment. Taylor and Francis e-Library.

Mackenzie, J. M. (1988). The Empire of Nature: Hunting, Conservation and British Imperialism. Manchester: Manchester University Press.

Mackenzie, J. M. (1995). Introduction. In Mrinalini Sinha. Colonial Masculinity: The 'Manly Englishman' and 'The Effeminate Bengali' in the Late Nineteenth Century. Manchester: Manchester University Press.

Mallet, M. L. (2008). Foreword. In Jacques Derrida. The Animal That Therefore I am. (Ed.) Marie-Luise Mallet. New York: Fordham University Press.

Morison, T. (1899). Imperial Rule in India: Being an Examination of the Principles Proper to the Government of Dependencies. London: A. Constable \& Co. Retrieved from <https://ia802605.us.archive.org/12/items/imperialruleinino31364mbp/imperialruleinino31364mbp.pdf>

Patterson, S. (2009). The Cult of Imperial Honor in British India. New York: Palgrave Macmillan.

Rajamannar, S. (2012). Reading the Animal in the Literature of the British Raj. New York: Palgrave Macmillan.

Rangarajan, M. (1998). The Raj and the natural world: The war against 'dangerous beasts' in colonial India. Studies in History, Vol. 14, No. 2 (265-299). Sage Publications. DOI https://doi.org/10.1177/025764309801400206

Sanderson, G.P. (1983). Thirteen Years Among The Wild Beasts of India. New Delhi: Mittal Publications.

Sholarin, M.A., Wogu, I.A.P., Omole, F., \& Agoha, B.E. (2015). "Man Is The Measure Of All Things": A Critical Analysis Of The Sophist Conception Of Man. Research On Humanities and Social Sciences, Vol. 5, No. 4. Retrieved From https://www.researchgate.net/publication/27407586o

Shakespeare, W. (2005). All's Well That Ends Well. (Webster's German Thesaurus Edition) ICON Classics. Retrieved from http://b-ok.org/book/810207/a6f899

Sinha, M. (1995). Colonial Masculinity: The 'Manly Englishman' and 'The Effeminate Bengali' in the Late Nineteenth Century. Manchester: Manchester University Press.

Taylor, J.O. (2007). Environmentalism and Imperial Manhood in Jim Corbett's Man-Eating Leopard of Rudraprayag. Mosaic: An Interdisciplinary Critical Journal, Vol. 4o, No. 4. (151-167). Retrieved From http://www.jstor.org/stable/44030399

Weil, K. (2012). Thinking Animals: Why Animal Studies Now? New York: Columbia University Press.

Parul Rani, a research scholar in English, in the Department of Humanities and Social Sciences, IIT Roorkee. Email Id: parulnet.e@gmail.com. ORCID Id: oooo-ooo2-9934-3585

Nagendra Kumar, a professor of English in the Department of Humanities and Social Sciences, IIT Roorkee.Email Id:naguk2o@gmail.com 